Agro-Science Journal of Tropical Agriculture, Food, Environment and Extension Volume 15 Number 1 January, 2016 pp. 23-28

ISSN 1119-7455

\title{
COWPEA FOR A CHANGING ENVIRONMENT IN THE RAINFOREST OF SOUTH-SOUTH NIGERIA
}

\author{
Ewansiha*, S.U. and Osaigbovo, A.U. \\ Department of Crop Science, Faculty of Agriculture, University of Benin, Benin City, Nigeria \\ *Corresponding author: Email: sylvester.ewansiha@uniben.edu; Tel.: +2348056351478 or \\ $+2348134920763$
}

\begin{abstract}
The introduction and use of appropriate cowpea varieties in south-south Nigeria may contribute to increased food security, especially in the context of the changing climate and desert encroachment in the country. In the context of evaluating diverse cowpea varieties for the changing environment, the present study involved the evaluation of 94 varieties of cowpea in 2013 and 2014 at Benin City in the rainforest of south-south Nigeria to identify varieties with the potential to contribute to grain or forage production and those with the potential for dual-purpose/multiple use. Grain yields of 0.5-2.0 $t$ hat $a^{-1}$ and biomass (fodder) of 0.9-4.4 $\mathrm{tha}^{-1}$ were obtained. Thirty-seven varieties that may contribute to grain production, 20 varieties that may contribute to biomass production and 13 varieties with potential for both grain and biomass production were identified. The observed potential to contribute to grain production, feed for livestock and crop residues for soil nitrogen improvement suggests cowpea may be a desirable option for use in mitigating the effect of climate change in the context of shift in crops and animals that can be produced in an environment that is changing.
\end{abstract}

Keywords: Climate change, cowpea, grain yield, biomass, south-south Nigeria

\section{INTRODUCTION}

Cowpea (Vigna unguiculata [L.] Walp) is an important grain and fodder legume in Nigeria where its tolerance to moisture stress, heat and low soil fertility makes it suitable for cultivation in the savanna agro-ecological zone (IITA, 2009). Animals such as cattle, sheep and goats are mainly reared in this zone which uses cowpea fodder and haulms as feed. However, the environment is changing due to climate change (increase in heat and drought) and desert encroachment in the savanna and change in rainfall patterns in the rainforest with erratic and lesser rainfalls accompanied by gradual change in vegetation (Odjugo 2010; Idowu et al., 2011). Growing period is shortening in the savanna due to climate change. Available arable land in northern Nigeria is getting smaller due to desertification.

Meanwhile, the late cropping season in the rainforest has potential for cowpea production. Climate change and desertification is presenting even a unique opportunity to grow cowpea in this zone. A consequence of climate change is a shift in animals and crops that can be grown in zones of traditional production. For example, in recent times the rainforest of Nigeria has experienced heightened herding activities with its attendant social/cross cultural challenges. Presently, hardly can one find a village in Edo state, for example, without Fulani nomads and their animals.

Even though cowpea is a major staple food for the people in south-south Nigeria, the price is very high because of cost of transportation from the northern to southern parts of the country. Price of the commodity could become cheaper if cowpea is grown in the region. In the region, there has also been a dearth of information on cowpea research and this has become very important in the face of the emerging challenges of climate change. Moreso, a fall in cowpea production in Nigeria will result in serious food security crisis in the whole of West and Central Africa because Nigeria does not only harbour all the agro-ecological zones; it is also the largest producer and consumer of cowpea in the region (IITA, 2009). As it happens to Nigeria so it happens to West and Central Africa. One way to avert this is for the breeder to breed for shorter duration cowpea for the savanna or for the agronomist to adapt cowpea varieties to the rainforest or both. Fortunately, there are many available genotypes of cowpea with diverse growth habits bred by the International Institute of Tropical Agriculture (IITA) (IITA, 2009). Some of these genotypes may have potential to grow and produce good 
grain and fodder yields in the rainforest of Nigeria. Cowpea adapted and grown in the rainforest will provide feed for the cattle; sheep and goat now found in the region as well as provide food for humans and improve the declining soil fertility of the rainforest occasioned by continuous cropping through crop residue generation and decomposition. Therefore, the objective of this study was to evaluate some varieties of cowpea for grain and biomass production potential in the rainforest as a way to mitigate the emerging threat of climate change on food security.

\section{MATERIALS AND METHODS \\ Experimental Site}

The experiment was conducted in the late cropping seasons (late August - December) of 2013 and 2014, at the Teaching and Research Farm of the Faculty of Agriculture, University of Benin, Benin City (06 20 'E, 5’ 39' E; 78 m asl) in the Rainforest of South-south Nigeria. The soils are underlain by sands, clayey sands and discontinuous clay sequences of Benin Formation of the Niger Delta Basin classified as ultisols (Olatunji et al., 2014, Umweni et al., 2014). Rainfall is of high intensity and bimodal, beginning in March/April and ending in October/November with a dry little spell in August usually referred to as "August Break". About $2025 \mathrm{~mm}$ of precipitation falls annually in Benin City with an average annual temperature of $26.1{ }^{\circ} \mathrm{C}$ (Climate-Data.org, 2016). The zone has a total growing period of 211 to 270 days (Ogeh and Ukodo, 2012). The period from the commencement of rain to the time of "August Break" is regarded as early cropping/growing season whereas the period from the break in August to the end of rains is regarded as the late cropping/growing season. The late cropping season was chosen for the experiment because it appears to be the most suitable for cowpea production in the Rainforest zone since it contains the months that present growing environments similar to those present in the savanna zones where cowpea is mainly grown. The rainfall and temperature during the years of trial together with the long-term rainfall and temperature are given in Table 1. Soil properties of the experimental site prior to start of the experiment are presented in Table 2.

Plant Materials and Experimental Layout

Ninety-four cowpea varieties obtained from the International Institute of Tropical Agriculture, Kano were evaluated in the study. The experiment was non-replicated having plot size of $3 \mathrm{~m} \mathrm{x} 2 \mathrm{~m}$ with $0.75 \mathrm{~m}$ between plots. Plant spacing was $0.75 \mathrm{~m}$ between rows and $0.20 \mathrm{~m}$ within rows and there were four rows per plot.

\section{Cultural Practices}

The field was cleared of vegetation manually, using cutlass. On 02 September 2013 and 01 September 2014, seeds of cowpea were sown at the rate of three seeds per hole at a depth of $5 \mathrm{~cm}$ and later thinned to two plants per hill at two weeks after sowing. Neither organic nor inorganic fertilizers were applied as the soil was deemed relatively fertile. Plants were sprayed against insect pests at the beginning of flowering using Uppercott (30 g cybermethrin $/ 230 \mathrm{~g}$ dimethoate per litre) at the rate of one litre per hectare. This was repeated at 10 days interval until when it was two weeks to harvesting. Spraying with fungicide (Z-force mancozeb $80 \%$ wp. Family: ethylene bidithiocarbamate EBDC manufactured by Jubali Sino agro chemical industry LTD, China) was done at 10 weeks after sowing to control fungal disease. Weeding was carried out using a hand hoe at two weeks after sowing and just before flowering to keep the plots weed-free.

\section{Data Collection}

The time of $95 \%$ pod maturity (i.e., when $95 \%$ of the pods in a plot had turned brown) was recorded. Number of branches and number of peduncles in a net plot (the two central rows) of a plot were determined and calculated as no. $\mathrm{m}^{-2}$. Mature pods in a net plot were harvested, counted and threshed; pod counts from the net plot were calculated as no. $\mathrm{m}^{-2}$ while the seeds were weighed and seed weights calculated as $\mathrm{kg} \mathrm{ha}^{-1}$ with adjusted moisture at $15 \%$. Above ground biomass (leaf and stem) was assessed at harvesting. Plants within the net plot were cut at $10 \mathrm{~cm}$ above the ground and oven dried at $65^{\circ} \mathrm{C}$ until constant weight was achieved. Weights of biomass were calculated as $\mathrm{kg} \mathrm{ha}^{-1}$.

\section{Data Presentation and Analysis}

Mean of the two-year data collected was subjected to correlation analysis, using the PRINCORR procedure of SAS programme (SAS, 2011). This was done to explore the relationship among the attributes. Two criteria were used to select promising varieties: high grain yield and high biomass based on the objectives of the study. To achieve this, frequency distributions were constructed for grain yield and biomass. Good biomass would help to identify varieties that may contribute to cowpea residue for soil improvement or livestock production while good grain yield would bring to light those varieties good for grain production; those suitable for dual purpose would also be identified. Frequency distributions were done by dividing the range for each variable by seven, which was the chosen number of class intervals using the 
empirical relationship suggested by Sturges (1926) as a guide and as stated below:

$K=1+3.3 \log _{10} n$; where $k$ is number of classes and $n$ is total number of observations.

\section{RESULTS AND DISCUSSION \\ Growing Conditions}

Mean rainfall during the experimental period (September - December) was $542 \mathrm{~mm}$ with a mean temperature of $27^{\circ} \mathrm{C}$ (Table 1). Soil samples collected before establishing the trial had a $\mathrm{pH}\left(\mathrm{H}_{2} \mathrm{O}(1: 1)\right.$ of 4.5 , organic carbon content of $9.3 \mathrm{~g} \mathrm{~kg}^{-1}$, total nitrogen (Kjeldahl) of $1.07 \mathrm{~g} \mathrm{~kg}^{-1}$, Olsen phosphorus (P) content of $19.64 \mathrm{ug} \mathrm{g}^{-1}$ and potassium content of 10.0 mmol (+) kg-1 soil $^{-1}$ (Table 2). These conditions provided an adequate environment for the cowpea crop to germinate, emerge, establish, grow and produce good yield. However, as with cowpea elsewhere, insect pests were serious problems. But more damaging without apparent control measure was the Quelea (Quelea quelea) birds that fed on the immature pods. However, the damage occurred most along border plots. Such damaged plots where excluded from the analysis and study which reduced the number of tested varieties from 94 to 75 .

\section{Agronomic Performance}

Time to maturity ranged from 61 to 99 days. Number of branches ranged from 1-33, number of peduncles from 25-222 and number of pods from 29-150 m , respectively. Biomass and grain yield ranged from 875.84356.0 and 475.4-2023.0 kg ha ${ }^{-1}$, respectively. Cowpea may be grouped into early (55-69 days), medium (70-85 days) and late (above 85 days) maturing varieties (Singh et al., 1997). Based on this, four varieties were early maturing, 68 medium maturing and three late maturing. According to Kamara et al. (2011), most early maturing, medium maturing and late maturing cowpea varieties have determinate, semi-determinate and indeterminate growth habits, respectively. While determinate cowpea varieties are grain-type cowpea, dualpurpose cowpea is either semi-determinate or indeterminate. In the context of providing fodder or generating crop residues, cowpea biomass can be a rich source of protein for animals or soil enrichment (IITA, 2009). Thus, cultivation of dual-purpose cowpea can be an attractive option for many farmers who would need to improve their impoverished soils occasioned by continuous cropping. With increasing number of herds migrating from the north to the south, cowpea fodder will help drive productivity and sustainability.

\section{Relationship among Traits}

Correlations between traits of the cowpea varieties studied are summarized in Table 3. Days to maturity was positively and significantly associated with biomass yield $(\mathrm{r}=$ $0.327, \mathrm{P}=0.0013$ ) whereas it was negatively and significantly associated with grain yield $(\mathrm{r}$ $=-0.238, \mathrm{P}=0.0211)$. This is why the medium and late maturing varieties had more biomass and less grain yields. There were significant and positive correlations between grain yield and biomass $(\mathrm{r}=0.513, \mathrm{P}<0.0001)$; number of pods $(\mathrm{r}=0.861, \mathrm{P}<0.0001)$; number of peduncles $(\mathrm{r}=0.520, \mathrm{P}<0.0001)$ and number of branches $(\mathrm{r}=0.475, \mathrm{P}<0.0001)$; between biomass and number of pods $(\mathrm{r}=0.572, \mathrm{P}<$ $0.0001)$; number of peduncles $(\mathrm{r}=0.545, \mathrm{P}<$ $0.0001)$ and number of branches $(\mathrm{r}=0.524, \mathrm{P}$ $<0.0001)$; between number of pods and number of peduncles $(\mathrm{r}=0.614, \mathrm{P}<0.0001)$ and number of branches $(\mathrm{r}=0.544, \mathrm{P}<0.001)$; and between number of peduncles and number of branches ( $\mathrm{r}=0.563, \mathrm{P}<0.001)$. These correlations indicate that grain yield depends on biomass, branch, and peduncle and pod production. Correlation between grain yield and yield components have been reported by several workers. Tamilselvam and Das (1994) studied correlation in cowpea and reported that seed yield per plant was positively correlated with number of branches and pods per plant.

Table 1: Rainfall and temperature at the experimental site for both long-term and 2013-2014 period

\begin{tabular}{|c|c|c|c|c|c|c|c|c|c|c|c|c|}
\hline \multirow{4}{*}{$\begin{array}{l}\text { Month } \\
\text { Jan }\end{array}$} & \multicolumn{4}{|c|}{ Long-term $\dagger$} & \multicolumn{4}{|c|}{2013} & \multicolumn{4}{|c|}{2014} \\
\hline & \multirow{2}{*}{$\begin{array}{c}\text { Rainfall } \\
(\mathrm{mm})\end{array}$} & \multicolumn{3}{|c|}{ Temperature $\left({ }^{\circ} \mathrm{C}\right)$} & \multirow{2}{*}{$\begin{array}{c}\text { Rainfall } \\
(\mathrm{mm})\end{array}$} & \multicolumn{3}{|c|}{ Temperature $\left({ }^{\circ} \mathrm{C}\right)$} & \multirow{2}{*}{$\begin{array}{c}\text { Rainfall } \\
(\mathrm{mm})\end{array}$} & \multicolumn{3}{|c|}{ Temperature $\left({ }^{\circ} \mathrm{C}\right)$} \\
\hline & & Min & $\operatorname{Max}$ & Av & & Min & Max & $\mathrm{Av}$ & & Min & Max & $\mathrm{Av}$ \\
\hline & 9 & 21.1 & 31.7 & 26.4 & 29.0 & 24.0 & 32.0 & 28.0 & 21.5 & 24.7 & 32.4 & 28.6 \\
\hline Feb & 44 & 21.8 & 32.7 & 27.2 & 33.0 & 24.2 & 32.8 & 28.5 & 6.7 & 24.5 & 32.5 & 28.5 \\
\hline Mar & 109 & 22.3 & 32.6 & 27.4 & 105.5 & 23.9 & 33.1 & 28.5 & 108.7 & 24.3 & 32.9 & 28.6 \\
\hline Apr & 164 & 22.9 & 32.1 & 27.5 & 113.2 & 23.4 & 31.9 & 27.7 & 132.7 & 23.6 & 32.1 & 27.9 \\
\hline May & 199 & 22.4 & 31.6 & 27.0 & 231.9 & 23.2 & 31.9 & 27.5 & 154.6 & 23.3 & 32.3 & 27.8 \\
\hline Jun & 267 & 21.8 & 29.4 & 25.6 & 358.6 & 23.0 & 30.4 & 26.7 & 208.5 & 23.3 & 31.2 & 27.3 \\
\hline Jul & 331 & 21.2 & 27.8 & 24.5 & 274.3 & 22.7 & 28.6 & 25.7 & 139.0 & 22.9 & 29.2 & 26.1 \\
\hline Aug & 247 & 21.2 & 27.8 & 24.5 & 255.3 & 22.5 & 28.1 & 25.3 & 437.2 & 22.4 & 28.6 & 25.5 \\
\hline Sep & 338 & 21.7 & 28.2 & 24.9 & 257.7 & 23.2 & 29.3 & 26.3 & 246.0 & 23.3 & 30.3 & 26.8 \\
\hline Oct & 233 & 21.8 & 30 & 25.9 & 225.0 & 23.6 & 30.6 & 27.1 & 116.6 & 23.1 & 30.3 & 26.7 \\
\hline Nov & 62 & 21.8 & 31.6 & 26.7 & 106.6 & 22.8 & 31.4 & 27.1 & 125.0 & 23.1 & 31.6 & 27.4 \\
\hline Dec & 22 & 20.5 & 31.6 & 26 & 6.5 & 20.9 & 33.1 & 27.0 & 0.6 & 23.7 & 33.8 & 28.8 \\
\hline Total & 2025 & & & & 1996.7 & & & & 1697.1 & & & \\
\hline
\end{tabular}


Table 2: Physical and chemical properties of soil for the experiment prior to planting in 2013

\begin{tabular}{ll}
\hline Properties & Concentration \\
\hline Sand & $810 \mathrm{~g} \mathrm{~kg}^{-1}$ \\
$\mathrm{Silt}$ & $40 \mathrm{~g} \mathrm{~kg}^{-1}$ \\
Clay & $150 \mathrm{~g} \mathrm{~kg}^{-1}$ \\
$\mathrm{pH}\left(\mathrm{H}_{2} \mathrm{O}(1: 1)\right.$ & 4.5 \\
Organic carbon content & $9.3 \mathrm{~g} \mathrm{~kg}^{-1}$ \\
Total nitrogen (Kjeldahl) & $1.07 \mathrm{~g} \mathrm{~kg}^{-1}$ \\
Olsen phosphorus (P) content & $19.64 \mathrm{ug} \mathrm{g}^{-1}$ \\
Potassium content & $10.0 \mathrm{mmol}(+) \mathrm{kg}^{-1}$ soil $^{-1}$ \\
\hline
\end{tabular}

Kamara et al. (2011) reported that grain yield had a positive association with number of pods and fodder yield for determinate cowpea varieties and positive association with fodder yield for semi-determinate cowpea varieties. Manggoel and Uguru (2011) reported significant and positive relationship between grain yield and number of peduncles and number of pods. Ewansiha et al. (2015) reported marked and positive correlation between grain yield and number of branches, number of peduncles, number of pods and fodder yield in cowpea varieties. Based on these findings, breeding for higher number of branches, peduncles, pods or fodder yield will lead to higher yields. With more biomass, cowpea tends to become dual in purpose.

\section{Selection of High Yielding and Dual- Purpose Varieties}

Frequency distributions of biomass and grain yield are presented in Table 4. Based on the classes, varietal values were scored for biomass and grain yield as shown in Tables 4 and 5 ( $1=$ very poor; $7=$ outstanding). Based on biomass, 20 varieties having high biomass were selected. These varieties scored well to outstanding performance for biomass. These can be used as fodder-type cowpea. This is very pertinent in the south-south environment where herding is becoming an increasing trend. Alternatively, the selected varieties with potential for biomass can be used as a resource for improving the soil in crop residue generation. This is very important in situations where continuous cropping has resulted in impoverished soils or where bush fallow has become too short to be able to replenish the soil. Based on grain yield, 37 varieties were selected because they had high grain yield. These varieties scored good to outstanding performance for grain yield and hence can be used as grain-type cowpea. For dual-purpose use, 13 varieties with high grain plus high biomass yields were identified.

Figure 1 shows all the selected varieties for fodder, grain and dual-purpose use. These varieties are mostly medium maturing, meaning that they have enough time for biomass accumulation and short enough maturity to escape terminal drought. While such varieties have yield potential of at least $2 \mathrm{t} \mathrm{ha}^{-1}$ for grain and $2 \mathrm{t} \mathrm{ha}^{-1}$ for fodder (Singh et al., 2003) in the savanna, the present study recorded a mean of $1.4 \mathrm{t} \mathrm{ha}^{-1}$ grain yields and $2.8 \mathrm{t} \mathrm{ha}^{-1}$ biomass/fodder yields for the selected varieties.

Table 3: Correlation coefficients between traits of cowpea varieties grown in a Rainforest environment

\begin{tabular}{lccccc}
\hline Trait & Days to maturity & Number of branches & Number of peduncles & Number of pods & Fodder yield \\
\hline Number of branches & -0.057 & & & & \\
Number of peduncles & 0.088 & $0.563^{* *}$ & & & \\
Number of pods & -0.182 & $0.544^{* *}$ & $0.614^{* *}$ & & \\
Fodder yield & $0.327^{* *}$ & $0.524^{* *}$ & $0.545^{* *}$ & $0.572^{* *}$ & \\
Grain yield & $-0.238^{*}$ & $0.475^{* *}$ & $0.520^{* *}$ & $0.861^{* *}$ & $0.513^{* *}$ \\
\hline
\end{tabular}

*significant at $5 \%$ level of probability; **significant at $1 \%$ level of probability

Table 4: Frequency distributions and selection scores for cowpea varieties

\begin{tabular}{lcccc}
\hline Selection attributes & Variety value & Selection score* & Number of varieties & Remarks \\
\hline Biomass $\left(\mathrm{kg} \mathrm{ha}^{-1}\right)$ & $876.0-1394.0$ & 1 & 18 & Very poor \\
& $1395.0-1913.0$ & 2 & 24 & Poor \\
$1914.0-2432.0$ & 3 & 13 & Fair \\
& $2433.0-2951.0$ & 4 & 11 & Good \\
& $2952.0-3470.0$ & 5 & 6 & Very good \\
& $3471.0-3989.0$ & 6 & 2 & Excellent \\
& $3990.0-4508.0$ & 7 & 1 & Outstanding \\
Grain yield $\left(\mathrm{kg} \mathrm{ha}^{-1}\right)$ & $475.0-696.0$ & 1 & 5 & Very poor \\
& $697.0-918.1$ & 2 & 18 & Poor \\
& $919.0-1140.0$ & 3 & 15 & Fair \\
& 1141.01362 .0 & 4 & 18 & Good \\
& $1363.0-1584.0$ & 5 & 6 & Very good \\
& $1585.0-1806.0$ & 6 & 8 & Excellent \\
& $1807.0-2028.0$ & 7 & 5 & Outstanding \\
\hline
\end{tabular}


Ewansiha, S.U. and Osaigbovo, A.U.

Table 5: Maturity group, biomass, grain yield and scores* for selection of high yielding varieties

\begin{tabular}{|c|c|c|c|c|c|c|}
\hline Variety & Days to maturity & $\begin{array}{c}\text { Biomass } \\
(\mathrm{kg} / \mathrm{ha})\end{array}$ & $\begin{array}{l}\text { Grain yield } \\
(\mathrm{kg} / \mathrm{ha})\end{array}$ & $\begin{array}{c}\text { Score for } \\
\text { biomass yield }\end{array}$ & $\begin{array}{l}\text { Score for grain } \\
\text { yield }\end{array}$ & Total \\
\hline IT06K-121 & & 1178.6 & 1094.5 & 1 & 3 & 4 \\
\hline IT07K-188-44 & & 883.0 & 915.8 & 1 & 2 & 3 \\
\hline IT97K-461-4 & $61.0-67.0$ & 1186.1 & 806.8 & 1 & 2 & 3 \\
\hline IT97K-499-39 & & 875.8 & 618.3 & 1 & 1 & 2 \\
\hline Aloka Local & & 2003.1 & 1370.8 & 3 & 5 & 8 \\
\hline Danila & & 1596.5 & 1668.7 & 2 & 6 & 8 \\
\hline IAR-48 & & 986.3 & 575.7 & 1 & 1 & 2 \\
\hline IT00K-1263 & & 3169.0 & 1781.9 & 5 & 6 & 11 \\
\hline IT03K-130 & & 1315.7 & 777.1 & 1 & 2 & 3 \\
\hline IT03K-316-1 & & 2054.1 & 1162.2 & 3 & 4 & 7 \\
\hline IT03K-324-9 & & 1210.0 & 1204.3 & 1 & 4 & 5 \\
\hline IT03K-335-9 & & 1788.5 & 1068.8 & 2 & 3 & 5 \\
\hline IT03K-337-6 & & 1238.0 & 1384.0 & 1 & 5 & 6 \\
\hline IT03K-351-1 & & 2691.7 & 1789.8 & 4 & 6 & 10 \\
\hline IT03K-351-9 & & 3418.5 & 1788.4 & 5 & 6 & 11 \\
\hline IT03K-378-4 & & 1537.5 & 896.9 & 2 & 2 & 4 \\
\hline IT04K-227-4 & & 1788.4 & 1187.6 & 2 & 4 & 6 \\
\hline IT04K-333-2 & & 1133.5 & 1172.7 & 1 & 4 & 5 \\
\hline IT04K-516-1 & & 2890.1 & 1391.8 & 4 & 5 & 9 \\
\hline IT06K-111 & & 1426.8 & 965.9 & 2 & 3 & 5 \\
\hline IT06K-111-1 & & 3591.1 & 1872.1 & 6 & 7 & 13 \\
\hline IT06K-121-3 & & 1406.1 & 801.8 & 2 & 2 & 4 \\
\hline IT06K-133 & & 1409.1 & 1128.8 & 2 & 3 & 5 \\
\hline IT06K-135 & & 1250.7 & 747.5 & 1 & 2 & 3 \\
\hline IT06K-212-1 & & 2449.5 & 1031.4 & 4 & 3 & 7 \\
\hline IT06K-270 & & 1826.5 & 728.5 & 2 & 2 & 4 \\
\hline IT06K-275 & & 1392.7 & 1144.8 & 1 & 4 & 5 \\
\hline IT06K-91-1 & & 1354.3 & 769.7 & 1 & 2 & 3 \\
\hline IT07K-187-72 & & 1525.9 & 1015.1 & 2 & 3 & 5 \\
\hline IT07K-194-3 & & 1907.7 & 1598.2 & 2 & 6 & 8 \\
\hline IT07K-206-1-3 & & 1077.3 & 1157.5 & 1 & 4 & 5 \\
\hline IT07K-211-1-8 & & 2379.5 & 1936.7 & 3 & 7 & 10 \\
\hline IT07K-212-4-3 & & 1288.9 & 1280.7 & 1 & 4 & 5 \\
\hline IT07K-216-7 & & 3248.1 & 1257.4 & 5 & 4 & 9 \\
\hline IT07K-220-1-9 & & 1814.7 & 1233.8 & 2 & 4 & 6 \\
\hline IT07K-244-1-1 & & 1851.1 & 1297.5 & 2 & 4 & 6 \\
\hline IT07K-249-1-11 & & 1293.3 & 857.1 & 1 & 2 & 3 \\
\hline IT07K-252-2-10 & & 1698.9 & 1132.7 & 2 & 3 & 5 \\
\hline IT07K-260-5 & $71.0-85.0$ & 2105.1 & 915.1 & 3 & 2 & 5 \\
\hline IT07K-281-2-7 & & 2393.5 & 1400.4 & 3 & 5 & 8 \\
\hline IT07K-290-11 & & 1567.8 & 1207.1 & 2 & 4 & 6 \\
\hline IT07K-291-69 & & 2516.9 & 686.3 & 4 & 1 & 5 \\
\hline IT07K-292-10 & & 1524.2 & 938.1 & 2 & 3 & 5 \\
\hline IT07K-293-18 & & 2328.8 & 1412.1 & 3 & 5 & 8 \\
\hline IT07K-293-3 & & 1879.1 & 875.6 & 2 & 2 & 4 \\
\hline IT07K-297-15 & & 1944.4 & 937.5 & 3 & 3 & 6 \\
\hline IT07K-299-4 & & 1372.6 & 713.2 & 1 & 2 & 3 \\
\hline IT07K-301-3 & & 1252.3 & 1020.7 & 1 & 3 & 4 \\
\hline IT07K-302-20 & & 2267.9 & 1446.2 & 3 & 5 & 8 \\
\hline IT07K-302-27 & & 3739.2 & 1916.4 & 6 & 7 & 13 \\
\hline IT07K-303-1 & & 2555.1 & 801.2 & 4 & 2 & 6 \\
\hline IT07K-311-1 & & 2561.7 & 1246.7 & 4 & 4 & 8 \\
\hline IT07K-313-44 & & 3018.1 & 1848.3 & 5 & 7 & 12 \\
\hline IT07K-318-2 & & 1458.1 & 1061.6 & 2 & 3 & 5 \\
\hline IT81D-994 & & 1876.1 & 1063.8 & 2 & 3 & 5 \\
\hline IT87D-941-1 & & 2081.0 & 1061.1 & 3 & 3 & 6 \\
\hline IT90K-277-2 & & 1819.3 & 1168.8 & 2 & 4 & 6 \\
\hline IT93K-452-1 & & 2538.0 & 1328.3 & 4 & 4 & 8 \\
\hline IT97K-568-11 & & 2191.5 & 1633.8 & 3 & 6 & 9 \\
\hline IT98K-1111-1 & & 1765.3 & 1165.1 & 2 & 4 & 6 \\
\hline IT98K-1263 & & 2025.5 & 1067.0 & 3 & 3 & 6 \\
\hline IT98K-131-2 & & 2617.8 & 2023.2 & 4 & 7 & 11 \\
\hline IT98K-133-1-1 & & 3450.0 & 1671.0 & 5 & 6 & 11 \\
\hline IT98K-205-8 & & 2766.4 & 777.1 & 5 & 2 & 7 \\
\hline IT98K-409-4 & & 2576.1 & 1264.9 & 4 & 4 & 8 \\
\hline IT98K-503-1 & & 1308.3 & 990.7 & 1 & 3 & 4 \\
\hline IT98K-589-2 & & 1627.5 & 773.2 & 2 & 2 & 4 \\
\hline IT99K-1060 & & 2152.9 & 1305.1 & 3 & 4 & 7 \\
\hline IT99K-377-1 & & 2395.8 & 866.5 & 3 & 2 & 5 \\
\hline IT99K-494-6 & & 1623.7 & 1738.2 & 2 & 6 & 8 \\
\hline IT99K-529-2 & & 1621.8 & 877.8 & 2 & 2 & 4 \\
\hline IT99K-573-2-1 & & 1561.7 & 1159.8 & 2 & 4 & 6 \\
\hline IT04K-321-2 & & 2663.1 & 555.5 & 4 & 1 & 5 \\
\hline IT $89 \mathrm{~K}-288$ & $90.0-99.0$ & 3365.5 & 475.4 & 4 & 1 & 5 \\
\hline IT98K-1103-13 & & 4356.3 & 857.3 & 7 & 2 & 9 \\
\hline
\end{tabular}

* Criteria for score: Table 4 


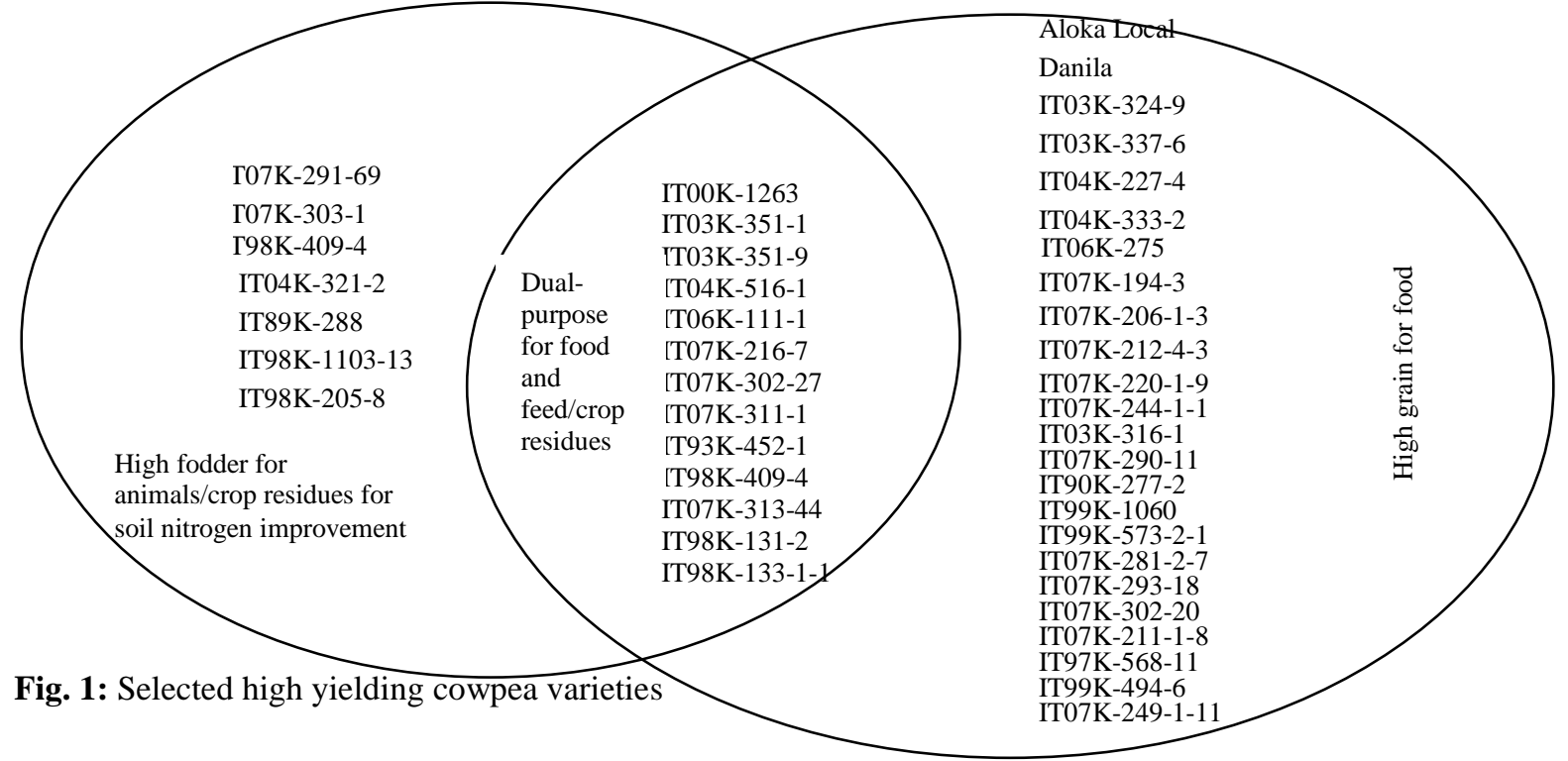

This implies that the selected varieties are well adapted to the rainforest and that the late growing season of south-south Nigeria may readily replace the Nigeria savanna in the context of changing environment due to climate change and desertification. This may be so because the growing environment in the savanna as typified by Minjibir in Kano, where the above yields were reported has similar rainfall and temperature as in Benin City during September-December when the present experiment was conducted. The long-term rainfall and temperature covering 30 years for Minjibir, Kano during July to October when cowpea is grown are $529 \mathrm{~mm}$ and $25.7^{\circ} \mathrm{C}$, respectively (Climate-Data.org, 2016b). This matches with the rainfall and temperature data for both long-term and current data (Table 1) for September to December in Benin City.

Thus, the application of these findings may help to mitigate the effect of climate change and desertification, ensure sustained food security especially when traditional crops may not be able to thrive in environments where they were once most adapted and grown.

\section{CONCLUSION}

Cowpea appears to have potential for use in the farming systems in the rainforest of south-south Nigeria where it can be grown for grain, fodder and soil improvement. A good number of the varieties were selected for their potential to contribute to high grain and fodder production while providing both grain and fodder. Further agronomic evaluations including planting date, plant population, insect pest infestation and diseases are warranted.

\section{ACKNOWLEDGEMENT}

The authors wish to acknowledge the contributions of Mr. Victor A. Shittu and Miss Aarinola O. Obe for their assistance with data collection. The research seed support by IITA, Kano station, is gratefully acknowledged.

\section{REFERENCES}

Climate-Data.org (2016a). Climate: Benin City. Available at http://en.climate-data.org/location/764230/. Accessed 18 Nov. 2016

Climate-Data.org (2016b). Climate: Minjibir. Available at http://en.climate-data.org/location/408164/. Accessed 18 Nov. 2016
Ewansiha, S.U., Kamara, A.Y., Chiezey, U.F. and Onyibe, J.E. (2015). Performance of cowpea grown as an intercrop with maize of different populations. African Crop Science Journal, 23 (2): 113-122

Idowu, A.A., Ayoola, S.O., Opele, A.I. and Ikenweiwe, N.B. (2011). Impact of Climate Change in Nigeria. Journal of Energy \& Environment, 2 (2): 145-152.

IITA (2009). Crops. Nigeria: International Institute of Tropical Agriculture; [accessed Jan 13, 2013]. Available from: http://www.iita.org

Kamara, A.Y., Tefera, H., Ewansiha, S.U., Ajeigbe, H.A, Okechukwu, R., Boukar, O. and Omoigu, L.O. (2011). Genetic gain yield and agronomic characteristics of cowpea cultivars developed in the Sudan savannas of Nigeria over the past three decades. Crop Science 51: 1877-1886

Manggoel, W. and Uguru, M.I. (2011). Comparative study on the phenology and yield components of two photoperiodic groups of cowpea (Vigna unguiculata (L.) Walp.) in two cropping seasons. African J. Agric. Res., 6 (23): 5232-5241

Odiugo, P.A.O. (2010). General overview of climate change impacts in Nigeria. J. Human Ecol. 29 (1): 47-55

Ogeh, J.S., and Ukodo, E. (2012). Profile distribution of physical and chemical properties in soils of a toposequence in Benin, rainforest of Nigeria. Nigerian J. Basic Applied Sci., 20 (1): 68-72

Olatunji, A.S., Abimbola, A.F. and Asowata, I.T. (2014). Geochemical Evaluation of Soils and Road Deposited Sediments of Benin City Using GIS and Multi-variance Approaches. British Journal of Applied Science \& Technology, 4(18): 2590-2606

SAS Institute Inc. (2011). The SAS system for Windows. Reslease 9.2. Cary, NC, USA: SAS Institute Inc.

Singh, B.B., Chamliss, O.L. and Sharma, B. (1997). Recent advances in cowpea breeding. p. 30-49. In: Singh, B.B., Mohan Raj, D.R. Dashiell, K.E. and Jackai, L.E.N. (ed.) Advances in Cowpea Research. Publication of IITA/JIRCAS. IITA. Ibadan, Nigeria

Singh, B.B., Ajeigbe, H.A. Tarawali, S.A., FernandezRivera, S. and Musa, A. (2003). Improving the production of cowpea as food and fodder. Field Crops Res., 84: 167-177

Sturges, H. (1926). The choice of a class-interval. $J$. American Statistics Association, 21: 65-66

Tamilselvan, A. and Das, L.D.V. (1994). Correlation studies in cowpea (Vigna unguiculata [L.] Walp.). for seed yield. Madras Agric. Journal, 81: 445-446

Umweni, A.S., Uwadiae, I. and Okunsebor, F.E. (2014). Evaluating the distribution of some selected heavy metals in the soils of a university community farm land in Mid-Western Nigeria. J. Res. Environ Earth Sci., 1(3), 1-16 